\title{
Pedagogical Support for Use of Information Technology in Teaching
}

\author{
Johanna Klassen \\ City University of Hong Kong, Hong Kong
}

Pdklasse@cityu.edu.hk

\begin{abstract}
With the advent of Information Technology (IT), there is a change happening in universities around the world. New information technologies are increasingly being integrated into the educational process to support pedagogy and learning. Teaching methods that use only the traditional lecture approach to teaching are increasingly seen as unsatisfactory. Good teaching has been identified by Chickering and Gamson (1987) as having seven attributes. This paper proposes that IT in teaching can involve all seven attributes of good practice. First, it provides literature support for IT use to achieve each of the attributes. Based on interviews carried out at City University of Hong Kong, recommendations are made for specific pedagogical support in order to support faculty better in the use of innovative technology.
\end{abstract}

Key words: innovative technology, instructional design support, life-long learning, managing educational systems

\section{Introduction}

With the advent of Information Technology (IT), there is a change happening in universities around the world. New information technologies are increasingly being integrated into the educational process to support pedagogy and learning. Faculty now can choose from a variety of instructional technologies to integrate into their syllabus. The computerbased technologies like word-processors, spreadsheets, and databases are almost as common as typewriters were twenty years ago. Graphics and desktop publishing software, as well as CD-ROMs, compact disc-interactive (CDI), DVD, hypertext, hypermedia, and multimedia tools bring new life into lecture presentations. The Internet broadens the sources of information and scope for sharing information. Telecommunication technologies such as audio-conferencing, videoconferencing, and computer conferencing, facilitate discussions with faculty, students, and experts from around the world.

Teaching methods that use only the traditional lecture approach to teaching are increasingly seen as unsatisfactory. This change is happening partly because students prefer to

Material published as part of this proceedings, either on-line or in print, is copyrighted by the author with permission granted to the publisher of Informing Science for this printing. Permission to make digital or paper copy of part or all of these works for personal or classroom use is granted without fee provided that the copies are not made or distributed for profit or commercial advantage AND that copies 1) bear this notice in full and 2) give the full citation on the first page. It is permissible to abstract these works so long as credit is given. To copy in all other cases or to republish or to post on a server or to redistribute to lists requires specific permission from the author. learn interactively and partly due to the demands of the work force. There is already a large percentage of older part-time students who are familiar with IT since they use it at work and thus are no longer content with the 'onetext/one-test/one-delivery-mode-fits-all' approach to teaching (Kember and Gow, 1994). They are expecting the use of IT tools in their courses. The second reason for the need for changing teaching methods is the demand of the work force. Employers now require employment-based generic skills, that is, graduates are expected to be versatile in a world of communications that includes tools such as email, Intranet, Internet, conferencing systems, and the World Wide Web, and also skills such as business awareness, adaptability, and problem solving (Davis, 1997; Dearing, 1997). Teichler (1999) adds that graduates are 'expected to work in teams' and 'to be versatile in generic skills which cut across different disciplines, and be literate in areas of knowledge which form the basis for various professional skills, for example in new technologies.'

Good teaching has been identified by Chickering and Gamson (1987) as having seven attributes. They believe that good practice in undergraduate education should: encourage student-faculty contact; encourage cooperation among students; encourage active learning; give prompt feedback, emphasize time on task; communicate high expectations and respect diverse talents and ways of learning. Chickering and Gamson identified these principles after '50 years of research on the way teachers teach and students learn.'

Given this premise, there is the question of whether each of these seven characteristics can be achieved through the use of Information Technology (IT) in teaching. This paper 


\section{Pedagogical Support}

proposes that IT in teaching can involve all seven attributes of good practice. First, it provides literature support for IT use to achieve each of the attributes. Based on interviews carried out at City University of Hong Kong, recommendations are made that could implemented in order to support faculty better in the use of innovative technology.

\section{Information Technology and Best Practice}

In this section we look at each of the seven attributes to see whether the literature supports the claim of good practice with the use of IT. The sources cited, taken almost exclusively from the 1990's, are but a small percentage of all reported claims of successful, innovative use of technology in teaching.

\section{Student-faculty contact}

Interaction capabilities through the use of IT substantiate Chickering and Gamson's (1987) claim that teacher-student contact is important for student motivation. Communication technologies can even increase the amount of communication between faculty and students. This is especially true for shy students who are afraid to speak up in class or visit a professor in his office. There are numerous studies substantiating this claim (Oblinger \& Rush, 1997; Tuller, 1997, especially evident in student ratings of teaching (Cohen, 1981; Marsh, 1984). As Chickering and Ehrman (1994) point out, the traditional communication between faculty and students is through assignments, a 'rather impoverished form of communication.' This common timedelay is no longer necessary. 'Now, however, electronic mail, computer conferencing, and the World Wide Web increase opportunities for students and faculty to converse and exchange work much more speedily than before, and more thoughtfully and "safely" than when confronting each other in a classroom or faculty office.'

\section{Cooperation among students}

Chickering and Gamson (1987) have noted that 'working with others often increases involvement in learning.' Chickering and Ehrmann (1994) propose that with new technologies 'learning is enhanced when it is more like a team effort than a solo race. Good learning, like good work is collaborative and social, not competitive and isolated.' Products such as Groupware also promote communication in asynchronous environments. The communication thus between 'geographically dispersed teams' is enhanced (Mayadas, 1997). Even in synchronous environments, learning networks encourage active participation in groups
(Oblinger \& Rush, 1997; Tuller, 1997; Norton \& Gonzales, 1998; Enhagen, 1997; Albright, 1999).

\section{Active learning}

Learning cannot be forced, it can only be assisted. From the constructivist perspective, learning occurs by the individual learner interacting with knowledge rather than processed from information received from an external source (Forcier, 1996; Roblyer, Edwards, \& Havriluk, 1997). So the process comes about through individual involvement in the construction of meaning. Albright, 1999, shows that the development of inquiry and insight can be achieved with the use of IT in teaching. The expanded access to current information (Albright, 1999; Oblinger and Rush, 1997) involves the learner in a meaningful way. Critical thinking occurs through evaluation of web information (Oblinger \& Rush, 1997), and higher order thinking skills (Norton \& Gonzales, 1998) are encouraged through the use of IT. Chickering and Ehrmann (1994) classify the communication technologies into three groups: tools and resources, time-delayed exchange, and real-time conversation. The electronic resources available to students in a library bring speed and efficiency into accessing journal articles, etc., on-line. The communication tools for faculty and student communication apply also to student-to-student communication.

An important benefit of the use of IT in teaching is the significant positive effect on achievement (Sivin-Kachala \& Bialo, 1995; Qin, Johnson, \& Johnson, 1995; Zammuner, 1995). Tynan (1993) claims there is a higher retention rate, especially with media that includes visual and audio cues. A Department of Defence study indicated that training with IT is approximately $40 \%$ more effective than traditional methods with a retention rate that is $30 \%$ greater (Dvorak \& Seymour, 1991). Slavin (1995) has examined 63 studies that report significant increase in learning effectiveness due to collaborative learning techniques. There is also substantial literature showing the effectiveness of online learning (Bruce, Peyton, \& Batson, 1993; Burge \& Collins, 1995; Hiltz, 1994; Waggoner, 1992). Further, there is considerable research to show that interactive multimedia technology potentially enhances learning (Burton, Moore, \& Thomas, 1995; Nelson, 1994; Nelson \& Palumbo, 1992).

Additionally, positive attitudinal changes towards learning and on student self-concepts can result from the use of IT (Sivin-Kachala \& Bialo, 1995). The use of cooperative learning techniques in combination with IT has also been shown to have positive effect on attitudes towards instructional content (Becker, 1992; Hooper, 1992; Hooper \& Hannafin 1991; Hooper, Temiyakarn \& Williams, 1993). 


\section{Prompt feedback}

Feedback acts as a mirror for learning. Without feedback, the learner may not even know what s/he doesn't know; without reflective help, a learner will only learn through trial and error. Poncelet \& Proctor (1993) define feedback as information about the appropriateness of the user's response that is provided by the courseware. Technology can allow for immediate feedback or delayed feedback, at whatever stage it is requested. It can be immediately after a task or after several tries to a task or it can be formative after projects or units (Klassen \& Milton, 1999). Researchers generally agree that the medium of technology is ideal for providing more timely and individualized feedback to the learner (Clariana, Ross, \& Morrison, 1991; Sponder \& Hilgenfeld, 1994; Sweeters, 1994; Deden \& Carter, 1996). In addition to the use of tools for feedback such as email and the 'track changes' on Microsoft Word, Chickering and Ehrmann (1994) suggest that video can be used to provide critical reflection for novice faculty and for students.

\section{Time on task}

Chickering and Gamson (1987) note that the more time students are engaged in a learning task, the more learning that takes place. A number of studies have shown that if students are working in pairs or collaboratively using IT, they are less likely to be distracted, to stay engaged in a task and as a result spend a longer time on task and to become more efficient (Brush, 1997; Klein \& Pridemore, 1992; Simsek \& Hooper, 1992). In self-paced learning, learners move on to new areas when they are ready and don't get bored because of materials that they already know. By only filling in gaps of missing information, they feel more motivated to learn (Najjar, 1996).

\section{Communication of high expectations}

As Chickering and Gamson (1987) suggest, expectations affect both the motivated and unmotivated. Berliner (1984) substantiates this claim. By treating students with a respect for their intelligence and setting attainable goals, learning increases; by setting low goals, the learning decreases. With the use of IT, students can set their own realistic goals and achieve them at their own pace (Bruder, 1991; Lamb, 1992). Students also work harder when they know their work will be open to the public on the World Wide Web.

\section{Respect for diverse talents and ways of learn- ing}

Chickering and Gamson (1987) show a healthy respect for the individual ways in which students learn. No two stu- dents use the same approach to learning, nor do they learn at the same pace. When technology is fused with pedagogy (Albright, 1999; Hooker, 1997) enhancement of learning takes place. With the use of IT, there is the opportunity to customize the learner's learning experiences and to accommodate different learning styles (Albright, 1999; Wild \& Quinn, 1998). Some students learn faster than others and prefer to move through materials quickly; this is especially true for surfing the Web. Others prefer to repeat sections or to learn at a slower pace and use the feedback or help that may be provided. Some may choose to work alone while others prefer to work in groups. IT respects these differences and provides for each of these differences.

It appears then that all 7 characteristics mentioned by Chickering and Gamson (1987) can be achieved with the use of IT in teaching. This use, however, cannot be seen as a panacea, a solution for all learning problems and situations. Clearly, there are issues to be resolved, but to ignore the potential that the use of IT can bring to our learning environments shows our lack of responsibility.

\section{Information Technology and Staff Development}

Since it has been demonstrated that technology can deliver the characteristics of good teaching and learning practice, it would be reasonable to expect that staff development programs would support staff in the use of new learning technologies. As Twigg (1994) argues, we must take into consideration the recent changes that have occurred in what students need to learn, how they learn, when they learn, where they can learn, and what students can access while they learn. Twigg argues against our 'current one-size-fitsall' approach to teaching. If the learning environment is changing so drastically, how can we afford not to change our teaching environment? How can professional development programs not support faculty in this transition? If technology has been shown to add to our teaching, not take away from it, why are faculty not given assistance in using it?

K.C. Green (1997) is well known for his surveys on use of technology on university campuses in America. In the 1997 National Survey of Information Technology in Higher Education he reports that 'assisting faculty integrate IT into instruction' and 'providing adequate user support' are the greatest challenges for institutions. In the survey, 29.6\% respondents cite 'instructional integration' as having top priority and $25 \%$ claim 'user support' as the highest need for institutions. 


\section{Pedagogical Support}

There are numerous examples of successful programmes at universities that are implementing change to include pedagogical support for instructional technology. These include Professional Development departments of universities successfully providing training for their faculty. The University of Florida (Truman-Davis et al, 2000) started an intensive faculty training program for creating interactive online learning environments where 200 faculty have participated in the program since 1996. The training "combines consultation with instructional designers, face-to-face meetings, labs, and online activities. Faculty receive financial incentives, support for course development, and assessment so their first online teaching attempts are successful.' Faculty report that they feel rejuvenated in their teaching as a result of this training. Facilitators report that the training not only provides the necessary skills for faculty, but it encourages 'discussion of pedagogical issues, models, and strategies; and facilitates teamwork between faculty participants, instructional designers, and the production team to produce the actual online course materials.'

At Virginia Tech the Instructional Development Initiative has offered support for faculty since 1993 (Taylor \& Eustis, 1999). In Phase II: Instructional Development Initiative, their instructional technology projects include new computing and network infrastructure and course redesign. 'The idea that faculty need both released time and considerable support (expert assistance, training, consulting, additional hardware and software) in order to revise and transform their courses has evolved from a novel luxury to an accepted expectation.'

At the University of Georgia the Office of Instructional Support and Development offers the Governor's Teaching Fellows (GTF) Program. Selected Fellows take a two-week course in summer and meet six times for three days during the academic year. They receive training in instructional development, design, and implementation of an instructional project. The course has been running since 1997 and is very well received (Gillespie; 1998). Another example is the credit bearing course offered by the Center for Teaching and Learning, Western Kentucky University, entitled 'Issues in Using the Internet in Instruction.' Participants are actively involved in designing a course and understanding principles of instruction adapted to the Internet (available at http://edtech.tph.wku.edu/ internet/.

\section{Faculty Interviews}

The main reporting structure of interviews was chosen so that in-depth discussions could be carried out. Although questionnaires are useful for general observations, the sug- gestions for improvement are generally more forthcoming in an interview.

Six full-time teaching faculty at CityU were interviewed individually in order to assess the need for pedagogical support for the use of IT in teaching. The research questions to be answered were:

i. Which technologies or infrastructure are most in demand at CityU?

ii. What are the perceived barriers at CityU to integrating IT into teaching?

iii. What can facilitate adoption of IT into teaching?

Of the six interviewees, two were frequent users of technology in teaching (referred to as Frequent -Users), two were beginning to use more technology (Modest-Users), and two rarely used technology (Non-Users). The interviews began with a discussion of the amount and type of technology used in teaching, as well as the problems encountered. The interviewee was then asked how City University could support them better in the use of technology in teaching. Two main areas were reported to be of concern to teaching staff: i. the infrastructure to support the use of IT in teaching, and ii. university policies regarding dissemination of good practice and rewards for innovative teaching practice.

\section{Discussion and Recommendations}

The results of the interviews have been integrated into generalized recommendations that could be implemented in any faculty development programme.

\section{Infrastructure}

\section{Physical Learning Environment}

There is a lack of teaching rooms that have full use of multimedia capabilities. Presentation panels are often available only in lecture theatres or laboratories and are out-dated with poor quality presentation so that students at the back are not able to see the presentation clearly. Most classrooms also do not have tools for collaborative learning where students can communicate electronically with faculty, peers and other professionals. This involves access to networked software. Additionally, rooms that are set up for use of IT in teaching often have tables that cannot be moved. For discussion purposes, the furniture cannot be moved around. This is not conducive to collaborative learning.

Deep integration of IT into teaching and learning is costly, but seems a necessity in this $21^{\text {st }}$ Century. Niemeyer and 
Black (1994) suggest that a technology enhanced learning environment should include the provision of smart classrooms with state-of-the-art projection systems, computers, document cameras, VCRs, network access, and control panels. Presentation panels are a necessity in every teaching room whether it be a lecture theatre, classroom, tutorial room or laboratory.

\section{Instructional Design}

Many faculty who are given no pedagogical support for teaching are simply placing handouts and a few PowerPoint slides on the web. This practice simply saves time and energy for the faculty who no longer need to print handouts and carry them to class since students print them now. This, however, does not add to creativity and interactivity. What is needed is individual instructional design to design lecture notes in a multimedia format. Novice users feel that they need someone not only to show them the possibilities of multimedia, but also to do it for them, at least until they have confidence in their ability to integrate technology into the curriculum.

Instructional design support needs to be readily available for all those who request help. Faculty need to meet with those who have pedagogical expertise and familiarity with IT to help them rethink their teaching approaches. Harrington (1991) affirms that just teaching faculty how to use technology is not enough. There is the need for them to understand how to integrate technology in a pedagogically sound manner appropriate to the particular content area.

There are times, however, when faculty development departments simply cannot generate the resources to help their faculty. Group discussions can then be used to help faculty transform their materials into multimedia format. Small groups can convene to discuss the best way of integrating these materials. Each faculty member brings materials to be considered for multimedia format and is given suggestions for development, as well as giving suggestions to others.

\section{Technical Support}

Technical assistance is needed for faculty to develop appropriate teaching resources in IT. This is true not only for the Non-Users of IT in a university. Although the 'Frequent-Users' are quite capable of doing the work themselves, it is very time-consuming. Many universities now are employing Student Helpers to create web pages for faculty. This can be helpful, but the complaint is that faculty cannot be guaranteed that by a certain date the site will be available. Student Helpers are unreliable, especially close to exam time. Student Helpers should therefore be added resources, not be the sole resources.

Additionally, a technology enhanced teaching environment should also provide adequate on-site trouble-shooting technical support so that help is available immediately when problems arise.

\section{Training Courses}

Training in most recent applications of IT needs to be available to teaching staff at several times in a semester. Green (1996) sees a growing demand for support personnel to assist and train faculty. What is also needed is training in a combination of approaches to using IT. This involves technical hands-on training from experts. Another possibility is for on-line staff development programs for use of IT (Gillespie, 1998; Gatlin-Watts, Arn, \& Kordsmeier (1999). The authors advocate, wherever possible, to incorporate 'just-in-time' and 'on-demand' delivery of faculty development programs and services for self-paced faculty development.

\section{Support/Integration after Training}

A Mentoring Scheme where experienced staff volunteer to help inexperienced staff would provide a follow-up after seminars and a source for faculty to go to when problems occur. Gilbert (1996) also recommends engaging experienced faculty as peer mentors. There is need for support beyond seminars and training courses. What is needed is a source for suggestions and improvements to ideas at the time when needed, not two weeks later when an appointment can be made. A Mentoring Scheme could solve this problem. Given a mentoring relationship, most faculty will make themselves available to colleagues who request their help. This would be an excellent way for faculty to observe a colleague's class, say, for example, a class using videoconferencing where students of Hong Kong liaise with students from Sydney. This could also be an opportunity for faculty to observe classes that are using Groupware for collaborative learning.

In a similar vein, a University circle could be formed for dissemination of good ideas. At each session a presenter would discuss his/her objectives and show how these were met or not met and what the benefits of using IT were to students. This would also provide examples of avoiding pitfalls. Colleagues should be encouraged to collaborate with one another. Gilbert (1996) recommends forming a Teaching, Learning and Technology (TLT) Roundtable that 


\section{Pedagogical Support}

facilitates communication, coordination, and collaboration within the university. This centralized organization provides opportunities for staff to discuss their innovations and to demonstrate the effectiveness in classes.

\section{University Policies}

\section{Dissemination of Good Practice}

Innovative faculty feel that they are living in isolation with no support for creative ideas in teaching. There is no mechanism whereby faculty can find out what others are doing to see if it could be of use to them. Very often faculty don't even know if they are re-inventing the wheel. This is substantiated by Massey, 1997, who feels that because faculty generally do not work together, they miss out on the experience gained by others. The mentioned authors support 'a propagation across the departments' so that faculty members have access to the work of others to see whether it might be applied to their situation.

\section{Use of IT seen as Scholarship}

A very common complaint from those who are implementing innovative practice in their teaching is the amount of time necessary for development of interactive multimedia materials and the lack of time allowed for such development. An exorbitant amount of time is needed beyond the normal teaching preparation time. Despite the added time it takes to incorporate technology into teaching, there is little incentive given to staff to spend time on this. There is no recognition for those who do take the time for innovation. This may result in an attitude of 'If no recognition is given, I'll spend my time on research which I know counts."

Extensive use of IT for instruction should therefore be incorporated into the Faculty Reward System. Most administrators have little comprehension of how to evaluate innovative faculty involvement with IT and new applications, nor do they understand the amount of time needed to develop such initiatives. This work should be recognized as scholarly work and credited to research undertaken. Heterick, (1993) president of EDUCOM, claims that it takes about as long to produce instructional courseware as it does to write a book.

In view of the time required to develop courseware for IT, it is recommended that teaching loads be reduced in order for faculty to develop materials and focus on innovation. Another possibility is for financial aid to be provided in order for faculty to hire technical help for developing mate- rials. Innovation in the use of IT definitely needs to be seen as scholarly work, to be recognized as research.

Green (1997) sees faculty recognition as an essential part of technology planning on campuses. He says, 'The vast majority of institutions are sending a clear if somewhat punitive message to faculty: do more with technology, but learn the skills on your own time and do it in addition to your other professorial responsibilities.' He reports that although more than $50 \%$ of institutions in America have IT support centers and instructional development programs, only $12.2 \%$ recognize or reward 'IT as part of routine faculty review and promotions' exercises. He also points to the lack of incentive faculty feel when they see no reward given to colleagues who do invest time. He believes this 'sends a chilling message about the institutional commitment to IT integration in instruction and scholarship.'

Recognition for training (certification) also needs to be given. Faculty need evidence of innovation for portfolios, internal assessments, etc. If recognition is not given, even experienced staff may give up, since innovation takes time away from publications that are required for tenure.

\section{Conclusion}

We are seeing a quiet revolution in our learning environments; we are witnessing a steady transformation in our approaches to teaching. The guru Peter Drucker gives universities just over thirty more years of operating in the traditional mode (quoted in West, 1999). The eventual integration of instructional technologies into this new environment is inevitable, whether courses are completely or partially taught on-line. What is needed is a widespread commitment by administrators to provide relevant infrastructure for this new approach.

This paper has focused on the need for more support for use of IT in teaching. Many faculty are facing a major transformation of teaching approaches without adequate guidance. Recommendations for infrastructure support include flexible smart classrooms with technical assistance available when necessary. Instructional design training and ongoing support after training are a necessity for a smooth transition of more innovation in teaching. Without supportive university policies that disseminate good practice and view IT as scholarship, faculty feel isolated. If they are encouraged or coerced to use more IT but do not have adequate support to carry this out, they will simply transcribe their text-based courses onto the web. This is a vast understatement of the possible innovations with the use of IT. Those who desire to use more IT tools but do not have instructional design support will feel great frustration with 
this transformation. It is incumbent on universities to support faculty in ways that are appropriate for the new millenium. Only with this support can faculty members be expected to infuse IT into their academic life.

\section{References}

Albright, M. (1999). Teaching in the Information Age: A New Look. In M.Theall, (Ed.) New Directions for Teaching and Learning. (80) pp.91-98, San Francisco: Jossey-Bass Publications.

Becker, (1992). A model for improving the performance of integrated learning systems: Mixed individualized/group/whole class lessons, cooperative learning, and organizing time for teacher-led remediation of small groups. Educational Technology, 32 (9), 5-15.

Berliner, D.C. (1984). The Half-Full glass: A Review of Resources in Teaching. In P.L. Hosford (Ed.) Using What we know about Teaching. Alexandria, Va: Association for Supervision and curriculum Development.

Bruce, B., Peyton, J.K. \& Batson, T. (1993). Network-based classrooms: Promises and realities. Cambridge, UK: Cambridge University Press.

Bruder, I. (1991). Guide to Multimedia: How it changes the way we teach and learn. Electronic Learning, September, 22-26.

Brush, T.A. (1997). The Effects on Student Achievement and Attitudes when using Integrated Learning Systems with Cooperative Pairs. Educational Technology Research and Development, 45 (1), 51-64.

Burge, Z., \& Collins, M. (1995). Computer mediated communications and the online classroom. Cresskill, NJ: Hampton Press.

Burton, J.K., Moore, D.M., \& Thomas, G.A. (1995). Hypermedia concepts and research: An overview. Computers in Human Behavior, $11(3 / 4), 234-370$.

Chickering, A.W., \& Gamson, Z. F. (1987). Seven Principles for good Practice in Undergraduate Education. AAHE Bulletin, 39 (7), 3-7.

Chickering, A. W. \& Ehrmann, S. C. (1994). Implementing the Seven Principles: Technology as Lever. American Association for Higher Education, available online: http://www.aahe.org

Clariana, R.B., Ross, S.M., \& Morrison, G.R. (1991). The effect of different feedback strategies using computer-administer multiplechoice questions as instruction. Educational Technology Research \& Development, 39, 5-17.

Cohen, P.A. (1981). Student Ratings of Instruction and Student Achievement: A Meta-Analysis of Multisection Validity Studies. Review of Educational Research, 51, 281-309.

Davis, N. (1997) Do Electronic Communications Offer a New Learning Opportunity in Education? In B. Somekh, \& N. Davis, (Eds.) Using Information Technology Effectively in Teaching and Learning, (167-180). London: Routledge.
Dearing Report. (1997). Report of the National Committee. Higher Education in the Learning Society, Crown, UK.

Deden, A., \& Carter, V. K. (1996). Using technology to enhance students' skills. New Directions for Higher Education, 96, 81-92.

Dvorak, J. \& Seymour, J. (1991). Just what is this multimedia thing good for, anyway? PC Computing, 54-55.

Enhagen, L. (Ed.) (1997). Technology and Higher Education. Washington, DC: National Education Association.

Forcier, R. C. (1996). Integrating technology for meaningful learning $\left(2^{\text {nd }}\right.$ ed.). Boston: Houghton Mifflin.

Gatlin-Watts, R., Arn, J., \& Kordsmeier, W. (1999). Multimedia as an instructional tool: Perceptions of college department chairs. Education Chula Vista, 120(1), 190-196.

Gilbert, S.W. (1996). Making the Most of a Slow Revolution. Change. $\underline{28}(2), 10-23$

Gillespie, K. H., (1998). The Impact of Technology on Faculty Development, Life, and Work. In R.J. Menges, \& M.D. Svinicki, (Eds.) New Directions for Teaching and Learning. (80), (pp. 1-5), San Francisco: Jossey-Bass Publishers.

Gillespie, K. H. (1998) Using Technology in Faculty Development: Practical Examples. In Gillespie, K. (Ed.) The Impact of Technology on Faculty Development, Life and Work. San Francisco: Jossey-Bass Ltd.

Green, K.C. (1996). The Upcoming Ubiquity of Information Technology, Change, 28 (2), 24-28.

Green, K.C. (1997). More Technology in the Syllabus, More Campuses Impose IT Requirements and Student Fees. The 1997 National Survey of Information Technology in Higher Education. Also available as:

http://ericir.syr.edu/Projects/Campus_computing/1997/index.html.

Harrington, H. (1991). Normal styletechnology in teacher education: Technology and the education of teachers. Computers in the Schools, 8 (1/2/3), 49-57.

Heterick, R.C. (1993). Re-engineering Teaching and Learning in Higher Education: sheltered Groves, Camelot, Windmills, and Malls. CAUSE Professional Paper Series 10, 3.

Hiltz, R. (1994). Virtual Classrooms. Norwood, JK: Ablex.

Hooker, M. (1997). The Transformation of Higher Education. In D. Oblinger, \& S. Rush, (Eds.) The Learning Revolution: The Challenge of Information Technology in the Academy (pp.20-34). Bolton, MA: Anker Publishing.

Hooper, S., (1992). Cooperative learning and computer-based instruction. Educational Technology Research and Development, 40(3), 21-38.

Hooper, S., \& Hannafin, M. (1991). The effects of group composition on achievement, interaction, and learning efficiency during computer- 


\section{Pedagogical Support}

based cooperative instruction. Educational Technology Research and Development, 39 (3), 27-40.

Hooper, S., Temiyakarn, C., \& Williams, M.D. (1993). The effects of cooperative learning and learner control on higher- and averageability students. Educational Technology Research and Develop$\underline{\text { ment, } 41}$ (2), 5-18.

Kember, D., \& Gow, L (1994). Orientations to teaching and their effect on the quality of student learning. Journal of Higher Education, 65 (1), 58-74.

Klassen, J. \& Milton, P. (1999). Decision-Making in the Pre-production Stages of Developing an Interactive Multimedia Package. In R.Bradbeer, (Ed.) Current Practice in Multimedia Education (pp. 19-32). Hong Kong: City University of Hong Kong Press.

Klein, J.D., \& Pridemore, D.R. (1992). Effects of cooperative learning and need for affiliation on performance, time on task, and satisfaction. Educational Technology Research and Development, 40(4), 39-47.

Lamb, A.C.(1992). Multimedia and the Teaching-Learning Process in Higher Education. In M.J. Albright \& D. L. Graf (Eds.) Teaching in the Information Age: The Role of Educational Technology (pp. 3342). 51, Jossey-Bass Publishers.

Marsh, H.W. (1984). Students' Evaluation of Teaching: Dimensionality, Reliability,

Validity, Potential Biases, and Utility. Journal of Educational Psychology, 76, 707-754.

Massy, W. (1997). Life on the Wired Campus. How Information Technology Will Shape Institutional Futures. In D. Oblinger, \& S.Rush, (Eds.) The Learning Revolution: The Challenge of Information Technology in the Academy (pp.195-210). Bolton, MA: Anker Publishing.

Mayadas, A. (1997). Asynchronous Learning Networks: New Possibilities. In D. Oblinger, \& S.Rush, (Eds.) The Learning Revolution: The Challenge of Information Technology in the Academy (pp. 211-230). Bolton, MA: Anker Publishing.

Najjar, L.J. (1996). Multimedia Information and Learning. Journal of Educational Multimedia and Hypermedia, 5(2), 129-150.

Nelson, W.A. (1994). Efforts to improve computer-based instruction: The role of knowledge representation and knowledge construction in hypermedia systems. In W.M.Reed, J.K. Burton, \& M. Liu (Eds.) Multimedia and megachange: New roles for educational computing (pp. 371-400). New York: The Haworth Press.

Nelson, W.A., \& Palumbo, D.B. (1992). Learning, instruction, and hypermedia. Journal of Educational Multimedia and Hypermedia, $1(3), 287-300$.

Niemeyer, D., \& Black, B. (1994). Smart Classrooms at the University of Colorado at Boulder. Paper presented at the Annual Convention of the Association for Educational Communications and Technology. Nashville, February, 1994.
Norton, P., \& Gonzales, C. (1998). Regional Education Technology Assistance Initiative-Phase II: Evaluating a model for statewide professional development. Journal of Research on Computing in education. 31 (1), 25-41.

Oblinger, D. \& Rush, S. (1997). The Learning Revolution. In D. Oblinger, \& S. Rush, (Eds.) The Learning Revolution: The Challenge of Information Technology in the Academy (pp. 2-19). Bolton, MA: Anker Publishing.

Poncelet, G.M., \& Proctor, L.F. (1993). Design and development factors in the production of hypermedia-based courseware. Canadian Journals of Educational Communication, 22 (2), 91-111.

Qin, Z., Johnson, D., \& Johnson, R. (1995). Cooperative versus competitive efforts and problem solving. Review of Educational Research, 65, 129-143.

Roblyer, A.D., Edwards, J., \& Havriluk, M.A. (1997). Integrating educational technology into teaching. Upper Saddle River, NJ: Prentice-Hall.

Simsek, A., \& Hooper, S. (1992). The effects of cooperative versus individual videodisc learning on student performance and attitudes. International Journal of Instructional Media, 19, 209-218.

Sivin-Kachala, J., \& Bialo, E. R. (1995). Report on the effectiveness of technology in schools, 1990-1994. Washington, DC: Software Publishers Association

Slavin, R.E. (1995). Cooperative Learning: Theory, Research, and Practice. Boston: Allyn and Bacon.

Sponder, B., \& Hilgenfeld, R. (1994). Cognitive guidelines for teachers developing computer-assisted instruction. The Computer Teacher, 22(8), 9-15.

Sweeters, W. (1994). Multimedia electronic tools for learning. Educational Technology, 47-52.

Taylor, C. D., \& Eustis, J. D. (1999). Assessing the Changing Impact of Technology on Teaching and Learning at Virginia Tech: A Case Study. In Katz, R. \& Rudy, J. (Eds.) Information Technology in Higher Education: Assessing Its Impact and Planning for the Future (54-70). San Francisco: Jossey-Bass Publishers.

Teichler, U. (1999). Higher Education Policy and the World of Work: Changing Conditions and Challenges. Higher Educational Policy, $\underline{12}, 285-312$.

Truman-Davis, B., Futch, L., Thompson, K., \& Yonekura F. (2000). Support for Online Teaching and Learning. Educause Quarterly, 2, 44-51.

Tuller, Charlie. (1997). Another Paradigm Shift. In D. Oblinger, \& S. Rush, (Eds.) The Learning Revolution: The Challenge of Information Technology in the Academy (pp. 35-53). Bolton, MA: Anker Publishing.

Twigg, C. (1994). The Need for a National Learning Infrastructure. Educom Review. 29, 4-6 
Klassen

Tynan, D. (1993). Multimedia goes on the job - just in time. New Media, 3, 38-46.

Waggoner, M.D. (1992). Empowering networks: Computer conferencing in education. Englewood Cliffs, NJ: Educational Technology Publications.

West, G. B. (1999). Teaching and technology in higher education: Changes and challenges. American Association for Adult \& Continuing Education, 10(4), 16-22.

Wild, M., \& Quinn, C. (1998). Implications of educational theory for the design of instructional multimedia. British Journal of Educational Technology, 29 (1), 73-82.
Zammuner, V.L. (1995). Individual and cooperative computer-writing and revising: Who gets the best results? Learning and Instructions, $\underline{5}, 101-124$.

\section{Biography}

Johanna Klassen is a faculty member of City University of Hong Kong, where she has 15 years of experience in teaching English. For the last 5 years she has been developing interactive multimedia courseware for teaching English. 